\title{
Mucinous Tubular and Spindle Cell Carcinoma of Kidney and Problems in Diagnosis
}

\section{Böbreğin Müsinöz Tübüler İğsi Hücreli Karsinomu ve Tanı Sorunları}

\author{
Banu SARSIK' ${ }^{\text {, Adnan ŞiMŞiR }}{ }^{2}$, Serap KARAARSLAN ${ }^{3}$, Sait ŞEN' \\ Department of ${ }^{1}$ Pathology, ${ }^{2}$ Urology, Ege University, Faculty of Medicine, IZMIR, TURKEY, ${ }^{3}$ Özel Ege Pathology Laboratory, IZMIR, TURKEY \\ This study was presented in part at the 18th National Pathology Congress at Antalya, held at October 25-29, 2008.
}

\begin{abstract}
Objective: Mucinous tubular and spindle cell carcinomas (MTSCC's) are recently described rare type of renal cell carcinoma (RCC). MTSCC's are characterized by small, elongated tubules lined by cuboidal cells and/or cords of spindled cells separated by pale mucinous stroma. They have morphological similarities to papillary RCC (papRCC). We evaluated the importance of the immunohistochemical features in the differential diagnosis of MTSCC and papRCC.
\end{abstract}

Material and Method: We re-evaluated 9 cases of MTSCC diagnosed between 2004 and 2010 and compared 10 cases of papRCC. All tumors were stained with alpha-methylacyl-CoA racemase (AMACR), cytokeratin 7 (CK7), CK19, renal cell carcinoma marker (RCC Ma), $\mathrm{CD} 10$ and kidney specific cadherin (KspCad).

Results: A total of 6/9 cases were considered classical. Two of 9 MTSCC's were classified as "mucin-poor". Foamy macrophages were identified in 4 cases. The immunoreactivity in MTSCC was AMACR 100\%, CK7 100\%, CK19 100\%, RCC Ma 50\%, CD10 11\%, and KspCad 38\% while the values for papRCC were AMACR 100\%, CK7 90\%, CK19 100\%, RCC Ma 100\%, CD10 80\%, and KspCad 0\%.

Conclusion: MTSCCs may include little mucin and show a marked predominance of either of its principal morphological components. They may mimic other forms of RCC. Pathologists should be aware of the histological spectrum of MTSCCs to ensure an accurate diagnosis. Careful attention to the presence of a spindle cell population may be helpful in the differential diagnosis in tumors with predominant compact tubular growth. Immunohistochemical stains for papRCC are also expressed in MTSCC, but strong CD10 expression may not favor MTSCC.

Key Words: CD10 Antigen, Renal cell carcinoma, Papillary renal cell carcinoma, Mucinous tubular and spindle cell carcinoma
ÖZ

Amaç: Müsinöz tübüler iğsi hücreli karsinomlar (MTİHK) son zamanlarda tanımlanmış nadir görülen renal hücreli karsinom (RHK) tipidir. MTİHK’lar küboidal hücrelerle döşeli uzun tübüller ve/veya iğsi hücrelerin oluşturduğu kordonlar arasında soluk müsinöz stroma ile karakterizedir. Papiller tipte RHK'lar (papRHK) ile benzer morfolojik özelliklere sahiptir. Biz MTİHK'lar ile papRHK arasındaki ayırıcı tanıda immünhistokimyasal özelliklerin önemini araştırdık.

Gereç ve Yöntem: 2004-2010 yılları arasında MTİHK tanısı almış olan 9 olguyu papRHK tanısı almış olan 10 olgu ile karşılaştırdık. Tüm tümörler alfa metil KoA rasemaz (AMACR), sitokeratin 7 (CK7), sitokeratin 19 (CK19), renal hücreli karsinom belirleyici (RCCMa), CD10, ve böbrek spesifik kaderin (BsKad) immünhistokimyasallarıyla boyand.

Bulgular: Dokuz olgunun altısı klasik tip MTİHK olarak değerlendirildi. Dokuz olgunun ikisi müsinden fakir olarak sınıflandı. Köpüksü makrofajlar olguların 4'ünde saptandı. MTİHK'larda AMACR \%100, CK7 \%100, CK19 \%100, RCCMa \%50, CD10 \%11, BsKad \%38, papRHK'larda ise AMACR \%100, CK7 \%90, CK19 $\% 100$, RCCMa \%100, CD10 \%80, BsKad \%0 reaktivite bulundu.

Sonuç: MTİHK'lar az miktarda müsin içerebilir, temel morfolojik özelliklerinden birisini daha belirgin gösterebilir ve diğer RHK'ları taklit edebilir. Patologların uygun tanı koyabilmesi için MTİHK'ların histopatolojik spektrumunun farkında olmaları gerekir. Belirgin tübüler gelişim olan tümörlerde, iğsi hücreli komponentin varlığına özenle dikkat edilmesi ayırıcı tanıda yardımcı olabilir. MTİHK için kullanılan immünhistokimyasal boyalar, papRHK'da da eksprese edilir fakat güçlü CD10 pozitifliği MTİHK lehine olmayabilir.

Anahtar Sözcükler: CD10 Antijeni, Renal hücreli karsinom, Papiller renal hücreli karsinom, Müsinöz tübüler iğsi hücreli karsinom 


\section{INTRODUCTION}

Mucinous tubular and spindle cell carcinoma (MTSCC) has been included in the 2004 World Health Organization Renal Cell Carcinoma (RCC) classification and is a rare, low grade and stage epithelial kidney neoplasm that generally has a good prognosis (1). Tumors with the same histopathological characteristics have been classified with various names in small series before the WHO classification (2-8). Authors have used various names for the histopathological appearance of these tumors that have tubules and spindle cells with a low nuclear grade and resemble the lower nephron or the loop of Henle. We believe these cases have been diagnosed as unclassified renal cell carcinoma (uRCC) solid variant of papillary of RCC (papRCC), sarcomatoid carcinoma and metanephric adenoma, in the past .

The characteristic feature during histological evaluation is small elongated tubules separated by a pale mucinous stroma with spindle cells between parallel tubules (1-14). However, the tubules, spindle-like and papillary areas, foam cells and mucinous stroma seen on histopathological evaluation can cause problems with the differential diagnosis when present at various degrees on histopathological sections and the spectrum of MTSCC has therefore been expanded (11).

The importance of immunohistochemical (IHC) studies in the differential diagnosis of renal tumors has been emphasized in various studies (15-30). Immunohistochemical markers including Cytokeratin 7 (CK7), Cytokeratin 19 (CK19), AMACR (P504S), Claudin 7, CD10, Renal Cell Carcinoma marker (RCCMa), CD15, Kidney specific cadherin (KsCad), EMA, CD117 (Ckit), and high molecular weight cytokeratin (hmwCK) have been used for MTSCC and their characteristics regarding the differential diagnosis emphasized (4-7, 10-13, 15-17). It has also been stated in these studies that papRCC and MTSCC have similar features and that one must be careful during the differential diagnosis.

Our aim in this study was to determine the histopathological and IHC features of cases diagnosed as MTSCC and to evaluate the contribution of IHC markers in the differential diagnosis with papRCC.

\section{MATERIAL and METHOD}

We included cases diagnosed as MTSCC among renal tumors evaluated at our department between 2004 and 2010 in the study and those that had been diagnosed as MTSCC during retrospective studies $(18,31)$. The clinial, demographical and radiological data of the cases were obtained from the hospital's archived records. All specimens of the cases were re-evaluated and the histological features recorded.

The MTSCC diagnosis was made according to the 2004 WHO definition and the histopathological features of the cases defined afterwards $(1,10-17)$. The main criteria were small elongated tubules and papillary structures separated by a pale mucinous stroma and spindle cells between the tubules. The tumors were staged according to the 2009 American Joint Committee on Cancer TNM classification and graded according to the Fuhrman system $(32,33)$.

MTSCC cases were classified as classical, tubular, spindle and papillary according to the prominent histopathological component. Other histopathological features such as the mucin content (poor, moderate, marked), the presence of necrosis and hemorrhage and changes in the surrounding renal parenchyma were also noted .

The AMACR, CK7, CK19, RCCMa, CD10 and KsCad IHC markers for which details are provided in Table I were used for the cases.

A demonstrative block containing renal parenchyma adjacent to the tumor was selected from the paraffinembedded formalin-fixed blocks of the cases for immunohistochemical evaluation. Sections $4-5 \mu \mathrm{m}$ thick were placed on electrostatic-charged slides (X-traTM, Surgipath Medical Industries, Richmond, Illinois, USA) and dried at $60^{\circ} \mathrm{C}$ for at least two hours. All IHC staining process took place on the BenchMark XT fully automatic immunohistochemistry staining device including deparaffinization and antigen exposure. The counterstaining of the sections in the device was completed with hematoxylin and the procedure was finalized by clearing with xylene and coverslip placement.

The staining characteristics of immunohistochemical markers in renal parenchyma tubule epithelial cells were used as the internal control. Semiquantitative evaluation according to the percentage of cells stained in the tumor was as follows: no staining $0,1-9 \%$ staining +1 (minimal), $10-24 \%$ staining $2+$ (focal), $25-49 \%$ staining $3+$ (moderate) and over $50 \%$ staining $4+$ (diffuse). Staning intensity was positive when focal, moderate or diffuse $(2,3,4+)$ and negative when there was no or minimal $(+1)$ staining.

AMACR, CK7, CK19, RCCMa, CD10 were used on the 10 recently diagnosed cases during 2009 and 2010 to compare the IHC features of PapRCC cases. KsCad could only be evaluated in 5 cases. The immunohistochemical staining features were compared with the MTSCC cases. 


\section{RESULTS}

There were 9 MTSCC cases. Of these 9 cases, 4 had been diagnosed as MTSCC while 5 had atypical diagnostic features and had been diagnosed during retrospective evaluations. A classical histological appearance was present in 6 cases and atypical features in 3 cases. There were 8 female cases. The mean age was $51 \pm 12$ and the median age 46. The clinical and demographical features of the cases have been presented in Table II.
There were varying degrees of mucin content and tubular and spindle-like areas in all cases (Figure 1A-F). We noted that the structural features could vary between cases and between areas in the same case. The general histopathological evaluation features are presented in Table III. No necrosis, papillary adenomatous changes or surrounding renal parenchyma changes were observed. One case had cells with clear cytoplasm in focal areas in addition to the typical morphological pattern.

Table I: The immunohistochemical markers used in the study and their features

\begin{tabular}{|l|c|c|c|c|}
\hline Antibody & Clone & Dilution & Company & Catalogue no \\
\hline RCC marker & PN-15 & $1: 100$ & Neomarkers & MS-409-P \\
\hline CD10 & 56C6 & $1: 100$ & Novo Castra & NCL-L-CD10-270 \\
\hline Cytokeratin 7 & OV-TL 12/30 & $1: 500$ & Neomarkers & MS-1352-P \\
\hline Cytokeratin 19 & A53-B/A2.26 & $1: 150$ & Neomarkers & MS-198-P \\
\hline AMACR & 13H4 & $1: 100$ & Dako & M3616 \\
\hline Kidney specific cadherin & MRQ 33 & ready & Ventana & 760487 \\
\hline
\end{tabular}

Table II: Demographic and clinical features and original diagnoses of MTSCC cases

\begin{tabular}{|c|c|c|c|c|c|c|c|c|}
\hline Case & Gender & Age & Side & Diameter & pT & Follow-up (months) & Surgery & Original diagnosis \\
\hline 1 & F & 64 & Left & 11.0 & pT2b & No & Radical & PapRCC-atypical features \\
\hline 2 & M & 55 & Right & 3.0 & pT1a & Continuing (60) & Partial & PapRCC-atypical features \\
\hline 3 & F & 33 & Right & 10.0 & pT2aN0 & No & Radical & PapRCC-solid variant \\
\hline 4 & F & 45 & Left & 21.0 & pT2bN0 & Continuing (59) & Radical & PapRCC-solid variant \\
\hline 5 & F & 44 & Left & 4.0 & pT1a & Continuing (6) & Radical & MTSCC \\
\hline 6 & F & 46 & Right & 6.0 & pT1b & Continuing (3) & Radical & uRCC-atypical MTSCC \\
\hline 7 & F & 69 & Left & 3.0 & pT1a & Continuing (23) & Radical & MTSCC \\
\hline 8 & F & 61 & Right & 12.5 & pT2b & Continuing (19) & Radical & MTSCC \\
\hline 9 & F & 46 & Right & 5.6 & pT1b & Continuing (9) & Radical & MTSCC \\
\hline
\end{tabular}

Table III: Histopathological features of the cases

\begin{tabular}{|l|c|c|c|c|c|c|c|}
\hline & Morphology & $\begin{array}{c}\text { Fuhrman } \\
\text { grade }\end{array}$ & Mucin content & Foam cells & Capsule & Hemorrhage & $\begin{array}{c}\text { Surrounding renal } \\
\text { parenchyma }\end{array}$ \\
\hline 1 & Classical & 2 & Marked & Moderate & Yes & No & Normal \\
\hline 2 & Classical & 2 & Few & No & No & No & Normal \\
\hline 3 & Tubular & 2 & Marked & Few & Yes & No & Normal \\
\hline 4 & Classical & 2 & Few & Marked & Yes & No & Normal \\
\hline 5 & Classical & 3 & Moderate & No & No & No & Normal \\
\hline 6 & Tubular & 2 & Moderate & No & Pseudo & Yes & Normal \\
\hline 7 & Tubular & 2 & Marked & No & Pseudo & No & Normal \\
\hline 8 & Classical & 2 & Marked & Moderate & Yes & No & Normal \\
\hline 9 & Classical & 2 & Moderate & No & Pseudo & Yes & Normal \\
\hline
\end{tabular}



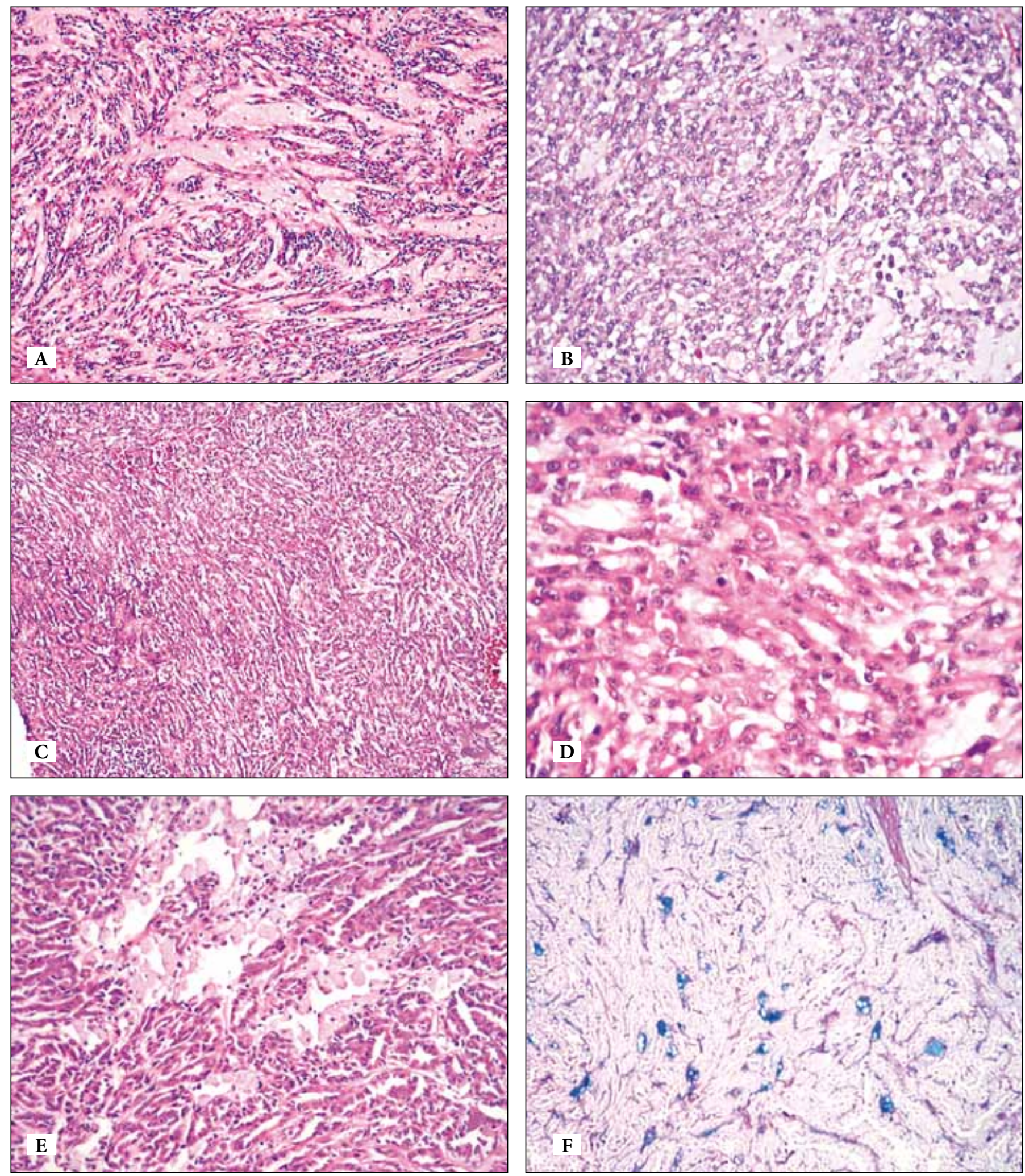

Figure 1: MTSCC show heterogenous features. The mucin content varies between cases and areas. A to $\mathbf{C}$ shows decreasing mucin content (H\&E, x10) while D has a classical appearance with eosinophilic cytoplasm and Fuhrman grade II nuclear features (H\&E, x20). E) Foam cells can be seen instead of mucin in some cases (H\&E, x10). F) The mucin content stains with alcian blue (x10). 
Features of IHC markers in the normal renal parenchyma. The immunohistochemical features of the distal and proximal tubules are presented in Figure 2A-D .

RCCMa; The brush borders of proximal tubular epithelum cells were more markedly positive with RCCMa in all cases.

CD10: We found positivity in the proximal tubule epithelial cells and the glomerular visceral and parietal epithelial cells in all cases.

CK 7: Distal tubular epithelial cells stained in all cases. There was also focal positivity in glomerular parietal epithelial cells in some cases.
CK 19: There was distal tubular epithelial cell positivity in all cases. There was weak focal positivity of glomerular parietal epithelial cells in some cases.

AMACR: All cases showed marked cytoplasmic positivity of proximal tubule cells. Some cases had weak focal positivity of glomerular parietal epithelial cells.

KsCad: All cases showed marked positivity at the basolateral section of the distal tubule cells. There was weak and mostly basal staining at the proximal tubules. There was no staining of the renal pelvis urothelial epithelum in two cases.
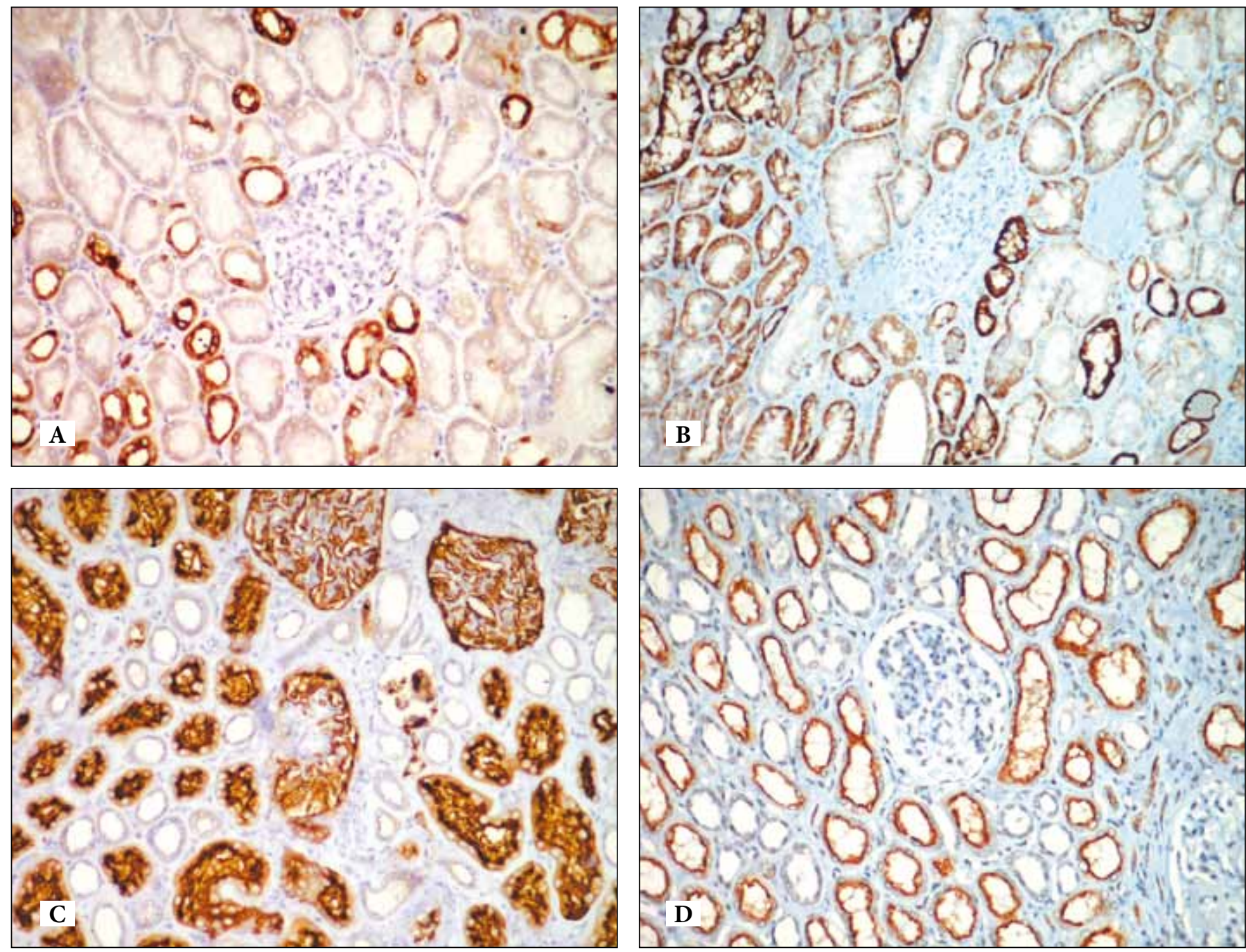

Figure 2: IHC staining patterns of distal and proximal renal tubule markers in the normal renal parenchyma. A) CK7, B) KsCad, C) CD10 and D) RCCMa. KsCad was positive in all tubules with the distal tubules being more prominent while CK7 was positive in distal tubule epithelial cells. CD10 was positive in glomerular epithelial cells (visceral and parietal) in addition to the proximal tubules and RCCMa shows apical positivity in the proximal tubules (x20). 
Table IV: Immunohistochemical features of MTSCC cases

\begin{tabular}{|c|c|c|c|c|c|c|}
\hline Case & CD10 & RCCMa & CK7 & CK19 & AMACR & KsCad \\
\hline $\mathbf{1}$ & 2 & 0 & 2 & 2 & 4 & 0 \\
\hline $\mathbf{2}$ & 1 & 0 & 4 & 4 & 4 & 3 \\
\hline $\mathbf{3}$ & 1 & 2 & 4 & 4 & None & 0 \\
\hline $\mathbf{4}$ & 0 & None & 4 & 4 & 3 & 0 \\
\hline $\mathbf{5}$ & 0 & 0 & 4 & 4 & 4 & 3 \\
\hline $\mathbf{6}$ & 1 & 3 & 2 & 2 & 2 & 0 \\
\hline $\mathbf{7}$ & 0 & 2 & 4 & 3 & 4 & 2 \\
\hline $\mathbf{8}$ & 0 & 1 & 4 & 3 & 4 & 0 \\
\hline $\mathbf{9}$ & 1 & 2 & 3 & None & 3 & None \\
\hline Positivity & $11 \%$ & $50 \%$ & $100 \%$ & $100 \%$ & $100 \%$ & $38 \%$ \\
\hline
\end{tabular}

Cases with a value above 2 were accepted as positive.

\section{IHC findings of MTSC:}

IHC findings and features are summarized in Table IV. In general, CK7, CK19, AMACR, and KsCad stainings were more intense in MTSCC while CD10 and RCCMa staining intensities were lower (Figure 3A-F). RCCMa positivity varied between areas and was weak. CD10 was negative except for one very weak case. It was not possible to evaluate RCCMa, CK19, AMACR and KsCad in one case.

\section{IHC findings of papRCC:}

AMACR, RCCMa and CK19 were 100\% positive while CK7 was $90 \%$ and CD10 $80 \%$ positive in papRCC cases. RCCMa and CD10 were generally apical and strongly positive. KsCad could only be studied in 5 cases due to availability problems and no positivity was observed.

Comparison of MTSCC cases with papRCC revealed that CK7, CK19, and AMACR staining characteristics were mostly similar while papRCC stained more strongly with RCCMa and CD10 while MTSCC cases had significant KsCad positivity.

\section{DISCUSSION}

We defined the histopathological and IHC characteristics of 9 MTSCC cases in this study. This is the largest MTSCC series from our country as far as we are aware and we compared the IHC differential diagnosis features with papRCC cases using multiple IHC markers. As in previous studies, 4 cases diagnosed during the first few years of the WHO 2004 classification had received a diagnosis of papRCC with atypical features and one case as MTSCC with atypical features. These cases were re-evaluated during other studies on renal tumors and the diagnoses revised as MTSCC $(18,31)$. The 289-case RCC series of Yazıc1 reports an MTSCC incidence of 2\% (5 cases) (18). The newlydiagnosed 4 cases were added to these cases and evaluated in this study.

MTSCC's are rare tumors and have been defined under various headers until being included in the WHO classification. These headers have generally been based on a diagnosis of unclassified renal tumors or have emphasized histological features. The main differential diagnosis problem is papRCC and the varying mucin and spindle cell content of MTSCC cases helps the differentiation. The IHC and genetic features of these tumors are also similar in addition to their histological features but a diagnosis of MTSCC is facilitated by increasing mucin and spindle cell content of the tumors while papillary and tubular structures and occasional foam cells make it more difficult. A spindle cell dominance may resemble sarcomatoid RCC or the sarcomatoid variant of papRCC. Similar diagnostic difficulties have been encountered in the literature. These two tumors have different prognostic features. MTSCC's are benign and no tumor-related death has been reported $(4-7,9-13)$ while papRCC, the second most common type of RCC at $10-15 \%$ has a 5 -year-survival rate of $90 \%$ (1, 8 ). It is therefore important to differentiate these tumors and also to differentiate the spindle component from RCC cases with sarcomatoid features that have an unfavorable prognosis.

The typical mucin and other characteristic histopathological features should indicate MTSCC. IHC markers may also help in the differential diagnosis. The tumor surrondings are quite helpful as a positive internal control with typical IHC marker features. These markers may also help tumor classification and cell origin determination. Previous studies have emphasized the features of IHC markers in the 

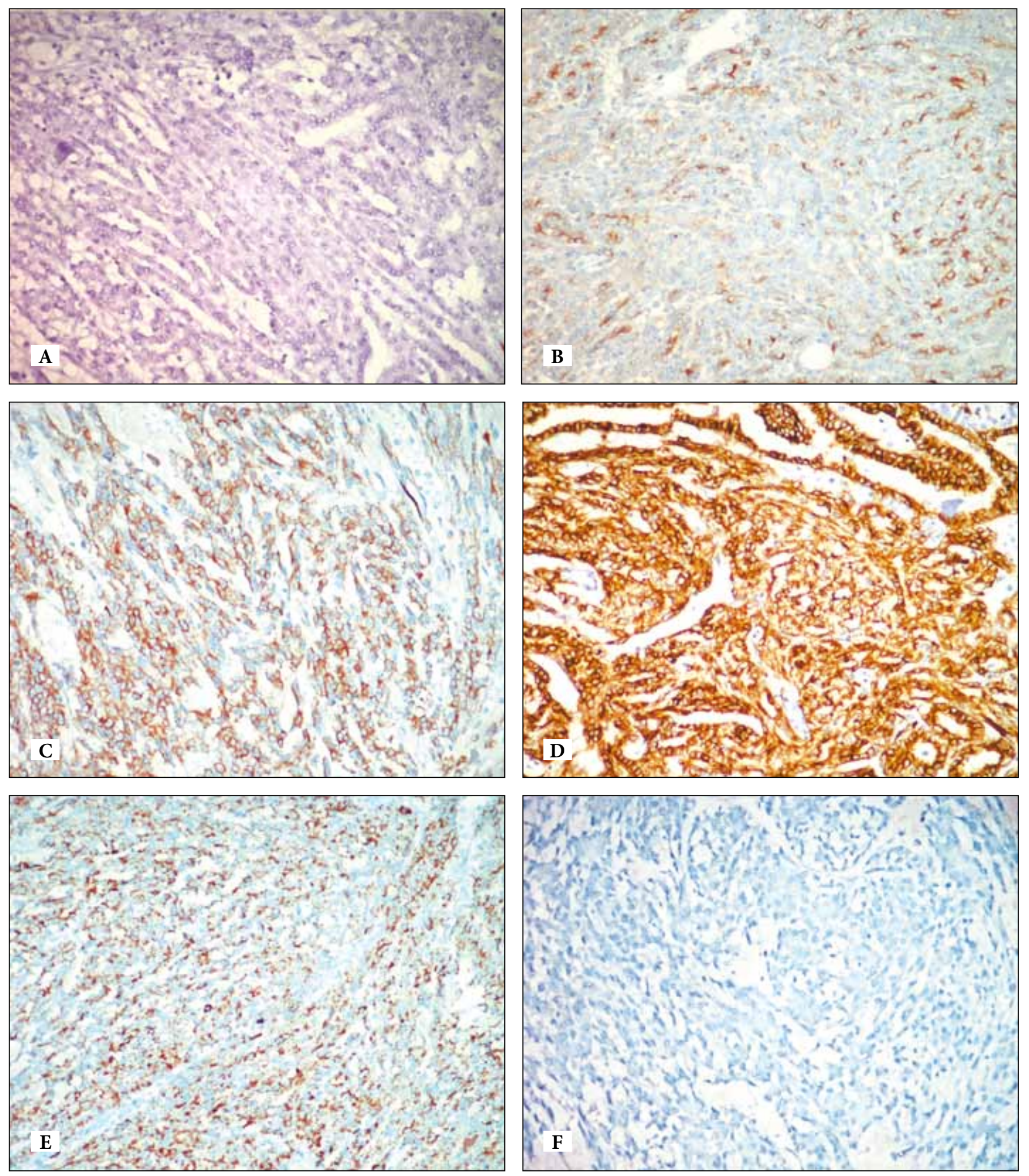

Figure 3: General features of IHC markers in MTSCC. A) CD10, B) RCCMa, C) CK 7, D) CK 19, E) AMACR, F) KsCad. The distal tubule markers CK 7 and CK 19 and the markers positive in the proximal tubules such as AMACR and RCCMa were found to be generally positive in MTSCC (x20). 
surrounding renal parenchyma $(12,13,15,34) . \mathrm{KsCad}$ is more markedly positive in distal nephrons.

IHC markers are helpful for the differential diagnosis of renal tumors especially in small needle biopsies (34). Many IHC markers have been used in MTSCC cases and the relationship with papillary tumors have been emphasized. Table V summarizes information from the current literature and our study. AMACR, CK7 and CK19 are diffuse positive in MTSCC cases.
AMACR is a marker that is positive in neoplastic cells of prostate adenocarcinomas. It is positive in renal proximal tubule epithelial cells while positivity in both MTSCC and papRCC seems to indicate a newly-acquired aberrant expression as regards cellular origin. EMA, CK7 and CK19 are positive in normal distal tubules. MTSCC cases are positive with EMA, CK7 and CK19. Similarly, papRCC cases show strong EMA, CK7 and CK19 positivity (12, 17, $18,23,29,30)$. These three markers are significant regarding tumors of distal tubule origin.

Table V: Comparison of the IHC staining profiles (percent) of MTSCC and papRCC

\begin{tabular}{|c|c|c|c|c|c|c|c|c|}
\hline Tumor & Source & Number of cases & RCCMa & CD10 & CK7 & CK19 & AMACR & KsCad \\
\hline \multicolumn{9}{|l|}{ MTSCC } \\
\hline & 4 & 6 & - & - & 100 & - & - & - \\
\hline & 5 & 5 & - & - & - & 80 & - & - \\
\hline & 6 & 4 & - & - & 100 & - & - & - \\
\hline & 7 & 11 & - & - & 66 & - & - & - \\
\hline & 10 & 15 & 45 & 21 & 100 & 100 & 100 & - \\
\hline & 11 & 13 & - & - & 92 & - & - & - \\
\hline & 12 & 27 & 7 & 15 & 81 & - & 93 & - \\
\hline & 13 & 12 & 92 & 17 & 92 & - & 92 & 8 \\
\hline & 15 & 23 & - & - & - & - & - & 0 \\
\hline & 16 & 4 & - & - & - & - & - & - \\
\hline & 17 & 3 & - & - & 100 & 67 & - & - \\
\hline & 41 & & $7-92$ & $9-50$ & $79-100$ & - & $92-100$ & - \\
\hline & our study & 9 & 50 & 11 & 100 & 100 & 100 & 38 \\
\hline \multicolumn{9}{|l|}{ papRCC } \\
\hline & 12 & 20 & 25 & 80 & 65 & - & 95 & - \\
\hline & 15 & 17 & - & - & - & - & - & 29 \\
\hline & 16 & 30 & - & - & - & - & - & - \\
\hline & 17 & 15 & - & - & 87 & 67 & - & - \\
\hline & 18 & 18 & 85 & 81 & 86 & 95 & - & - \\
\hline & 19 & 19 & 93 & 93 & - & - & - & - \\
\hline & 20 & 52 & 94 & - & - & - & - & - \\
\hline & 21 & 8 & 75 & 100 & - & - & - & - \\
\hline & 22 & 15 & - & - & - & - & 100 & - \\
\hline & 23 & 35 & - & - & - & - & 100 & - \\
\hline & 24 & 91 & - & - & 59 & - & - & - \\
\hline & 25 & 46 & - & - & - & - & - & 2 \\
\hline & 26 & 30 & 97 & - & - & - & - & 13 \\
\hline & 27 & 15 & - & - & - & - & - & 0 \\
\hline & 28 & 27 & 63 & 59 & 45 & - & - & - \\
\hline & 29 & 20 & - & - & 80 & 90 & - & - \\
\hline & 30 & 88 & 53 & 67 & 80 & & 87 & - \\
\hline & 41 & - & $87-95$ & $67-93$ & $80-87$ & & $80-100$ & $0-29$ \\
\hline & our study & 10 & 100 & 80 & 90 & 100 & 100 & 0 \\
\hline
\end{tabular}


The positivity rate with KsCad was $38 \%$. Kuehn et al. have not found any KsCad expression in MTSCC cases (15). Kuehn has used only 2 complete secions in his study and added 21 case studies with the microarray method. The positivity rates of other tumors were also low in Kuehn's microarray studies (15). Shen et al. have reported KsCad positivity as $8 \%$ (1/12 cases) and this positivity was in the tubular areas (13). The proximal tubule positivity in the renal parenchyma was reported as weak and focal in these two studies. We had positivity in the tubular areas in 3 of our 8 cases. Positivity could be easily found in the distal tubules of the normal surrounding parenchyma (Figure 2AD). This may be related to the concentration of the readyto-use antibody employed. KsCad positivity varies between 0 and $29 \%$ in papRCC cases $(13,15,25-27)$. We found KsCad positivity in 5 papRCC cases. KsCad has mostly been used for diagnosing oncocytomas and chromophobe RCC cases but the results of two studies are contradictory regarding differential diagnosis $(15,26)$. Shen and Kuehn have postulated that the lack of KsCad positivity in MTSCC cases indicated an origin other than the distal tubule but it is probably best to think of the negativity of this marker in both papRCC and MTSCC cases as being due to loss of expression in tumors $(15,26)$.

EMA is positive in $88 \%$ of MTSCC cases. Positivity was $95-$ $100 \%$ in 4 large studies while two other studies reported positivity rates of $36 \%$ and $69 \%(5-7,10-12)$. EMA positivity is $56-95 \%$ in papRCC cases $(12,28,30)$. There are also other studies where the differential diagnosis between papRCC and MTSCC was not helped by AMACR, CK7, CK19 or EMA. This is important regarding the cellular origin similarity of the two tumors.

The positivity rate was 50\% (4/8 cases) for RCCMa and $11 \%$ (1/9 cases) for CD10 in our study. RCCMa positivity has been reported as $7-92 \%$ in 3 studies $(10,12,13)$. Positivity has been defined as apical in all studies. Paner et al. have reported the smallest positivity rate and the RCCMa positivity in papRCC cases was also lower than the average rate in this study (12). CD10 positivity was $15-21 \%$ in 3 studies $(10,12,13)$. Positivity was apical in tubular areas and cytoplasmic in spindle areas. CD10 positivity has been reported at a rate of $59-100 \%$ for papRCC cases $(12,18,19$, $21,28,30)$. The weak and focal staining of CD10 seems to be important for differentiation from papRCC. RCCMa and CD10 are generally significant regarding the proximal tubule origin but the expression in papRCC cases can be interpreted as a newly-acquired feature.

The widening spectrum of MTSCC in recent years has led to the description of atypical, sarcomatoid and metastatic cases as well (35-40). It therefore seems more important to be aware of such morphological changes in MTSCC diagnosis and employ IHC analysis $(41,42)$. However, there are also cases that are extremely similar to papRCC in the differential diagnosis $(12,13)$. Fluorescent in situ hybridization or comparative genomic hybridization studies may take the place of IHC investigation in the differential diagnosis. These studies have reported multiple chromosomal losses including $1,4,6,8,11,13,14,18$, 22 instead of chromosomal additions $(5,9,10,39)$. The chromosome 3 losses that are typical for clear RCC have not been found. We are unaware of any genetic studies on MTSCC cases or renal tumors from our country.

In conclusion, MTSCC cases have both morphological and CK7, CK19, AMACR and RCCMa IHC marker features that are similar to papRCC cases. The CD10 expression rate is lower in these tumors and MTSCC diagnosis is less likely when this marker shows strong and diffuse positivity. Larger series correlated with advanced genetic analysis may provide more specific information on this matter.

\section{ACKNOWLEDGMENT}

We would like to thank Hayriye Köktaş and Dilek Pelvan for their help in the study and Bios Medikal for their help in supplying kidney specific cadherin.

\section{REFERENCES}

1. Srigley JR: Mucinous Tubular and Spindle Cell Carcinoma. In Eble JN, Sauter G, Epstein JI, Sesterhenn IA (Eds). World Health Organization, Tumours of the Urinary System and Male Genital Organs: Pathology and Genetics. Lyon, IARC Press, 2004, 40

2. MacLennan GT, Farrow GM, Bostwick DG: Low-grade collecting duct carcinoma of the kidney: report of 13 cases of low-grade mucinous tubulocystic renal carcinoma of possible collecting duct origin. Urology 1997, 50:679-684

3. Val-Bernal JF, Gómez-Román JJ, Vallina T, Villoria F, Mayorga M, García-Arranz P: Papillary (chromophil) renal cell carcinoma with mucinous secretion. Pathol Res Pract 1999, 195:11-17

4. Srigley JR, Eble JN, Grignon DJ, Hartwick RWJ: Unusual renal cell carcinoma (RCC) with prominent spindle cell change possibly related to the loop of Henle. Mod Pathol 1999, 12:107A

5. Rakozy C, Schmahl GE, Bogner S, Störkel S: Low-grade tubularmucinous renal neoplasms: morphologic, immunohistochemical, and genetic features. Mod Pathol 2002, 15:1162-1171

6. Parwani AV, Husain AN, Epstein JI, Beckwith JB, Argani P: Low-grade myxoid renal epithelial neoplasms with distal nephron differentiation. Hum Pathol 2001, 32:506-512

7. Hes O, Hora M, Perez-Montiel DM, Suster S, Curík R, Sokol L, Ondic O, Mikulástík J, Betlach J, Peychl L, Hrabal P, Kodet R, Straka L, Ferák I, Vrabec V, Michal M: Spindle and cuboidal renal cell carcinoma, a tumour having frequent association with nephrolithiasis: report of 11 cases including a case with hybrid conventional renal cell carcinoma/ spindle and cuboidal renal cell carcinoma components. Histopathology 2002, 41:549-555 
8. Eble JN: Mucinous tubular and spindle cell carcinoma and postneuroblastoma carcinoma: newly recognised entities in the renal cell carcinoma family. Pathology 2003, 35:499-504

9. Cossu-Rocca P, Eble JN, Delahunt B, Zhang S, Martignoni G, Brunelli $M$, Cheng L: Renal mucinous tubular and spindle carcinoma lacks the gains of chromosomes 7 and 17 and losses of chromosome $\mathrm{Y}$ that are prevalent in papillary renal cell carcinoma. Mod Pathol 2006, 19:488-493

10. Ferlicot S, Allory Y, Compérat E, Mege-Lechevalier F, Dimet S, Sibony M, Couturier J, Vieillefond A: Mucinous tubular and spindle cell carcinoma: a report of 15 cases and a review of the literature. Virchows Arch 2005, 447:978-983

11. Fine SW, Argani P, DeMarzo AM, Delahunt B, Sebo TJ, Reuter VE, Epstein JI: Expanding the histologic spectrum of mucinous tubular and spindle cell carcinoma of the kidney. Am J Surg Pathol 2006, 30:1554-1560

12. Paner GP, Srigley JR, Radhakrishnan A, Cohen C, Skinnider BF, Tickoo SK, Young AN, Amin MB: Immunohistochemical analysis of mucinous tubular and spindle cell carcinoma and papillary renal cell carcinoma of the kidney: significant immunophenotypic overlap warrants diagnostic caution. Am J Surg Pathol 2006, 30:13-19

13. Shen SS, Ro JY, Tamboli P, Truong LD, Zhai Q, Jung SJ, Tibbs RG, Ordonez NG, Ayala AG: Mucinous tubular and spindle cell carcinoma of kidney is probably a variant of papillary renal cell carcinoma with spindle cell features. Ann Diagn Pathol 2007, $11: 13-21$

14. Murphy WM, Grignon DJ, Perlman EJ: Tumors of Kidney, Bladder, and Related Urinary Structures. Washington DC, Armed Forces Institute of Pathology. Atlas of Tumor Pathology. 4th series, Fascicle 1, 2004

15. Kuehn A, Paner GP, Skinnider BF, Cohen C, Datta MW, Young $A N$, Srigley JR, Amin MB: Expression analysis of kidney-specific cadherin in a wide spectrum of traditional and newly recognized renal epithelial neoplasms: diagnostic and histogenetic implications. Am J Surg Pathol 2007, 31:1528-1533

16. Gupta R, Balzer B, Picken M, Osunkoya AO, Shet T, Alsabeh R, Luthringer D, Paner GP, Amin MB: Diagnostic implications of transcription factor Pax 2 protein and transmembrane enzyme complex carbonic anhydrase IX immunoreactivity in adult renal epithelial neoplasms. Am J Surg Pathol 2009, 33:241-247

17. Skinnider BF, Folpe AL, Hennigar RA, Lim SD, Cohen C, Tamboli P, Young A, de Peralta-Venturina M, Amin MB: Distribution of cytokeratins and vimentin in adult renal neoplasms and normal renal tissue: potential utility of a cytokeratin antibody panel in the differential diagnosis of renal tumors. Am J Surg Pathol 2005, 29:747-754

18. Yazıcı A: Böbrek adenokarsinomlarının ayırıcı tanısında immunhistokimyanın yeri. Uzmanlık tezi. Tez yöneticisi: Şen S. 2008 Available from:http://193.140.255.11/tezvt/tez.htm

19. Avery AK, Beckstead J, Renshaw AA, Corless CL: Use of antibodies to RCC and CD10 in the differential diagnosis of renal neoplasms. Am J Surg Pathol 2000, 24:203-210

20. McGregor DK, Khurana KK, Cao C, Tsao CC, Ayala G, Krishnan B, Ro JY, Lechago J, Truong LD: Diagnosing primary and metastatic renal cell carcinoma: the use of the monoclonal antibody 'Renal Cell Carcinoma Marker'. Am J Surg Pathol 2001, $25: 1485-1492$
21. Ordóñez NG: The diagnostic utility of immunohistochemistry in distinguishing between mesothelioma and renal cell carcinoma: a comparative study. Hum Pathol 2004, 35:697-710

22. Lin F, Brown RE, Shen T, Yang XJ, Schuerch C: Immunohistochemical detection of P504S in primary and metastatic renal cell carcinomas. Appl Immunohistochem Mol Morphol 2004, 12:153-159

23. Tretiakova MS, Sahoo S, Takahashi M, TurkyilmazM, Vogelzang NJ, Lin F, Krausz T, Teh BT, Yang XJ: Expression of alphamethylacyl-CoA racemase in papillary renal cell carcinoma. Am J Surg Pathol 2004, 28:69-76

24. Delahunt B, Eble JN: Papillary renal cell carcinoma: a clinicopathologic and immunohistochemical study of 105 tumors. Mod Pathol 1997, 10:537-544

25. Mazal PR, Exner M, Haitel A, Krieger S, Thomson RB, Aronson PS, Susani M: Expression of kidney-specific cadherin distinguishes chromophobe renal cell carcinoma from renal oncocytoma. Hum Pathol 2005, 36:22-28

26. Shen SS, Krishna B, Chirala R, Amato RJ, Truong LD: Kidneyspecific cadherin, a specific marker for the distal portion of the nephron and related renal neoplasms. Mod Pathol 2005, 18 : 933-940

27. Adley BP, Gupta A, Lin F, Luan C, Teh BT, Yang XJ: Expression of kidney-specific cadherin in chromophobe renal cell carcinoma and renal oncocytoma. Am J Clin Pathol 2006, 126:79-85

28. Pan CC, Chen PC, Ho DM: The diagnostic utility of MOC31, BerEP4, RCC marker and CD10 in the classification of renal cell carcinoma and renal oncocytoma: an immunohistochemical analysis of 328 cases. Histopathology 2004, 45:452-459

29. Langner C, Wegscheider BJ, Ratschek M, Schips L, Zigeuner R: Keratin immunohistochemistry in renal cell carcinoma subtypes and renal oncocytomas: a systematic analysis of 233 tumors. Virchows Arch 2004, 444:127-134

30. Allory Y, Bazille C, Vieillefond A, Molinié V, Cochand-Priollet B, Cussenot O, Callard P, Sibony M: Profiling and classification tree applied to renal epithelial tumours. Histopathology 2008, 52:158-166

31. Şen S, SarsıkB, Neşe N, Tuna B, Düzcan E, Özağarı A, Yörükoğlu $K$ : Böbrek tümörlerinde tanısal zorluklar ve immunhistokimyasal değerlendirmenin yeri. Türk Patoloji Derg 2009, 25 ek sayı, 9-10

32. Edge SB, Byrd DR, Carducci MA, Compton CC (Eds): AJCC Cancer Staging Manual. 7th ed. New York, NY, Springer; 2009

33. Fuhrman SA, Lasky LC, Limas C: Prognostic significance of morphologic parameters in renal cell carcinoma. Am J Surg Pathol 1982, 6:655-663

34. Şen S, B Sarsık, A Şimşir: Renal tümörlerde immunhistokimyasal belirleyiciler ve tümör dıșı renal parankim bulguları. Turk Patoloji Derg 2010, 26:120-129

35. Kuroda N, Naroda T, Tamura M, Taguchi T, Tominaga A, Inoue K, Shuin T, Lee GH, Hes O, Michal M: High-grade mucinous tubular and spindle cell carcinoma: comparative genomic hybridization study. Ann Diagn Pathol 2010 Nov 23 Epub ahead of print

36. Pillay N, Ramdial PK, Cooper K, Batuule D: Mucinous tubular and spindle cell carcinoma with aggressive histomorphology--a sarcomatoid variant. Hum Pathol 2008, 39:966-969 
37. Kuroda N, Tamura M, Hes O, Michal M, Kawada C, Shuin T, Lee GH: Renal cell carcinoma with extensive clear cell change sharing characteristics of mucinous tubular and spindle cell carcinoma and papillary renal cell carcinoma. Pathol Int 2009, 59:687-688

38. Dhillon J, Amin MB, Selbs E, Turi GK, Paner GP, Reuter VE: Mucinous tubular and spindle cell carcinoma of the kidney with sarcomatoid change. Am J Surg Pathol 2009, 33:44-49

39. Argani P, Netto GJ, Parwani AV: Papillary renal cell carcinoma with low-grade spindle cell foci: a mimic of mucinous tubular and spindle cell carcinoma. Am J Surg Pathol 2008, 32:1353-1359
40. Brandal P, Lie AK, Bassarova A, Svindland A, Risberg B, Danielsen H, Heim S: Genomic aberrations in mucinous tubular and spindle cell renal cell carcinomas. Mod Pathol 2006, 19: 186-194

41. Truong LD, Shen SS: Immunohistochemical diagnosis of renal neoplasms. Arch Pathol Lab Med 2011, 135:92-109

42. Şen S, B Sarsık, Şimşir A, Kısmalı E, Gökmen E: Böbrekte kitle nedeniyle yapılan iğne kor biyopsileri ve tanı zorlukları. Turk Patoloji Derg 2009, 25:5-18 